\title{
Educational Vouchers: Freedom to Choose?
}

\author{
Jordan Reel', Walter E. Block'
}

ABSTRACT Milton Friedman is famous for his book title: "Free to Choose." He also favors educational vouchers, which denies the freedom to choose to people who do not wish to subsidize the education of other people's children. Thus, he is guilty of a logical contradiction. Why is it important to assess whether Friedman's views on educational vouchers are logically consistent with his widespread reputation as an advocate of free enterprise, and, thus, freedom to chose? It is important to assess all figures in political economy, and indeed all of scholarship, for logical consistency. It is particularly important to do so in the present case, given the prestige in certain quarters accorded to this Nobel prize-winning economist. We argue in this paper that Friedman's reputation for logical consistency, and adherence to the philosophy of laissez faire capitalism, are both overblown. Our solution to this challenge is to completely privatize education. Friedman does not advocate that vouchers be utilized for food, clothing or shelter; we see no relevant difference in the case of education.

What is the justification of the undertaken topic? This topic is important because education of the next generation is crucial for the upkeep and improvement of society. What is the aim of the present study? It is to demonstrate that the solution offered by M. Friedman and R. Friedman (1990) is highly problematic. What is the methodology used in the study? We quote from this author, and criticize his analysis. What are our main results and conclusions/recommendations? We conclude that the last best hope for the educational industry is laissez faire capitalism, not the mixed economy recommended by Friedman.

KEY WORDS: $\quad$ economic freedom; choice; school vouchers; Milton Friedman

JEL Classification: $\quad$ 12; 128

${ }^{1}$ Loyola University, United States

\section{Introduction}

Milton Friedman is one of the most popular economists and classical liberal thinkers. A survey (Davis, Figgins and Klein, 2011) of favorite twentieth-century economists put him in second place in popularity, barely below Keynes. He is a sometime advocate of free markets, liberty, and personal choice and responsibility. His philosophy that there should be completely unregulated markets and his opposition to government

Correspondence concerning this article should be addressed to: Walter E. Block, Loyola University New Orleans 6363 St. Charles Avenue, Box 15, Miller Hall 318 New Orleans, LA 70118. e-mail: wblock@loyno.edu intervention and welfare has numerous exceptions. The present paper is devoted to an analysis of one of them: education.

In section II we claim that Friedman compromises with the tenets of economic freedom in the case of education. Section III is devoted to an exploration of public education. The burden of section IV, our concluding section, is to consider some possible solutions.

\section{Educational compromises}

Despite the title of their book, M. Friedman and R. Friedman (1990), does not focus on eliminating regulation and burdensome taxation regarding education. In Friedman (1983) he summed up the problems with 
education, "Monopoly and uniformity have replaced competition and diversity." The solution that he lays out in his book (M. Friedman \& R. Friedman 1990) is to stop government subsidizidation of public schools ${ }^{1}$ and instead subsidize the students. ${ }^{2}$ Each child will receive a voucher worth a certain amount of money that he can spend only on education. This program would ensure that every child gets an education at an institution of his choosing. However there are many flaws in this plan that result from several misunderstandings of education - and free markets.

In developing his theory on education, Friedman throws out the traditional framework for understanding economic phenomena. Opportunity costs, subjective value, the benefits of mutual exchange, and the importance of economic choices are all ignored. Compulsory education, coercive taxation and the importance of government mandated curriculum are accepted without question.

The benefits of schooling are assumed to outweigh the costs, justifying the required attendance laws and government funding of education. However, this statement cannot be made because of subjective value. When there is trade on a free market we can say that both parties benefit from the exchange in the ex ante sense. When there is no trade it is impossible to say whether or not there would be benefit from an exchange. No one can-quantify or objectify the valuations of other people. Only through voluntary trade can we say that people are made better off. Compulsory education laws remove the voluntary aspects of the interaction thus, rendering false the assumption that education benefits everyone.

Another unwarranted assumption is implied when standardized tests are used as the measure of the quality of schools (M. Friedman \& R. Friedman, 1990, p. 156): that there is somebody who knows for sure what students ought to learn. All pupils are grouped together as if they all demand to learn the same exact things. But each person is unique and has his own value systems and goals. Even for a single child it is impossible for a central planner to know what he should learn to maximize his productivity. To do this, a central planner would have to have the ability to predict the future, which is not possible because he cannot possess all the tacit knowledge of every actor in the economy. Before the twentieth century in the United States, school leaders thought it was important to teach Latin and Greek, but with the industrial revolution in the late nineteenth and early twentieth centuries, these studies were replaced by science. Especially with the speed of innovation, we see in the economy today, it is impossible to predict which inventions will come tomorrow and what knowledge they will require.

We readily acknowledge that characterizing Milton Friedman as a central planner will ring false in the eyes of many. He is widely known as a champion of laissez faire capitalism. However, his actual record does not at all support this reputation. ${ }^{3}$

Another important factor that is overlooked is opportunity cost. Even if we entertain Friedman's assumption that education is beneficial to all students, we still cannot say that all people would be best off if they were educated. The economist must look at the alternative goals that must be given up. By forcing children to go to school, resources are misallocated because children spend more time in education than they otherwise might have and tax payers pay more for education than they would have. Maybe the student's time would be more productive if he invested it in on the job training or maybe the taxpayer's money would be better spent on other, more valuable, goods. We do not know though, because consumers are not allowed to make that choice. "Free to choose," indeed.

The prosperity of the market depends on the economic freedom of people to make choices on how to use their own scarce resources. Out of these choices comes trade, savings, investment, and economic growth. Where these choices are limited by government intervention, so is wealth. It is amazing that in a book entitled Free to Choose that the importance of choice is so poorly appreciated, let alone understood. Choices driven by subjective values are made based on perceived opportunity costs and tacit knowledge (Hayek, 1948). Only by allowing choices to be made on a free market can the most productive actions take place. Vouchers limit choice. They require that a certain amount of money, extracted through coercive taxation, be spent on education. Students are able to use vouchers to choose among more schools but fully free economic decisions cannot be made.

Friedman's "solution" to education is for the government to gain control of the budgets of every family. By first taking income through taxation and then 
giving it back with restrictions on its use, a certain amount of income is forcefully appropriated for education. The central planner is given the power to control the spending of income of everyone. It is up to this central planner to decide the minimum that is to be spent on education.

The choice between schools, according to Friedman's plan would also be restricted by standards. He says "The voucher plan embodies exactly the same principle as the GI bills that provide for educational benefits to military veterans. The veteran gets a voucher good only for educational expense and he is completely free to choose the school at which he uses it, provided that it satisfies certain standards (M. Friedman, R. Friedman, 1990, p. 161)." When standards are required so is the central planner. The standards for what constitutes a school must be set by a politician or bureaucrat. Those that fit the preconceptions of what education should be will benefit from this as the innovative ones will be squelched. It cannot be otherwise. If no standards apply, then a bicycle shop, or a restaurant, might qualify.

The goal of the voucher system is to stimulate competition, the lack of which is the perceived problem. With $90 \%$ of k-12 students enrolled in public education (National Center for Education Statistics, "CCD Quick Facts"), the market-share is large enough for Friedman to consider public schools a monopoly, but he adopts a meaningless definition of this concept and overestimates the control government has on education.

Monopolies only exist when entry into an industry is prohibited by law. The concentration ratio of an industry is of little importance. Having a $90 \%$ marketshare is not necessarily monopolistic. The true problem with single-seller status is how it comes into being. There are two and only two ways this status can occur. First is voluntarily. A firm sells a product that consumers value more highly than the price they pay for it. The firm may be the first to create this product, or it may be able to produce a higher quality or less expensive version than any competitor. In this way, the single seller status is gained by serving the consumer better than any other firm. As long as new suppliers are legally able to enter the market, even if there is only one firm, there is the threat of potential competition. The second way, the monopolistic way, is through state prohibition of entry into the market. ${ }^{4}$
The low quality of education and the few options are not the result of a government monopoly. Subsidies force taxpayers to pay for education they otherwise would not purchase while compulsory attendance laws force students to consume a service they otherwise might not consume. On top of these laws is the socialist nature of public education. All of these hurt competition, but none of them are monopolistic. Competition is not prohibited by them.

What is the case for compelling childless people to contribute to the educational needs of others? Friedman (1972) resorts to neighborhood effects, or external economies. This is the idea that even those without offspring benefit when youngsters are educated. They are less likely to be criminals, more likely to vote intelligently, etc. States Friedman (1972) in this regard:

"A stable and democratic society is impossible without a minimum degree of literacy and knowledge on the part of most citizens and without widespread acceptance of some common set of values. Education can contribute to both. In consequence, the gain from the education of a child accrues not only to the child or his parents but also to other members of the society. The education of my child contributes to your welfare by promoting a stable and democratic society. It is not feasible to identify the particular individuals (or families) benefited and so to charge for services rendered. There is therefore a significant 'neighborhood effect.'

"What kind of governmental action is justified by this particular neighborhood effect? The most obvious is to require that each child receive a minimum amount of schooling of a specified kind."

This is highly problematic from various points of view. First of all, this claim of Friedman's puts paid even the more to his very precarious reputation (Rothbard, 2002) as a supporter of free enterprise. Advocates of laissez faire capitalism advocate less government intervention into economic affairs, not more. Secondly, Friedman confuses the normative and the positive. When he maintains that there are in effect spill-over effects, that the education of child X will benefit person $\mathrm{Y}$, even though the latter pays nothing for the former, he is firmly ensconced in the world of positive economics. But when he concludes from this that "governmental action is justified" he enters the realm of normative economics. He is deducing an "ought" from an "is," a process that has been eloquently refuted by Hume (1739, pp. 455-470), who states: 
"In every system of morality, which I have hitherto met with, I have always remark'd, that the author proceeds for some time in the ordinary way of reasoning, and establishes the being of a God, or makes observations concerning human affairs; when of a sudden I am surpriz'd to find, that instead of the usual copulations of propositions, is, and is not, I meet with no proposition that is not connected with an ought, or an ought not. This change is imperceptible; but is, however, of the last consequence. For as this ought, or ought not, expresses some new relation or affirmation, 'tis necessary that it shou'd be observ'd and explain'd; and at the same time that a reason should be given, for what seems altogether inconceivable, how this new relation can be a deduction from others, which are entirely different from it ... [I] am persuaded, that a small attention [to this point] wou'd subvert all the vulgar systems of morality, and let us see, that the distinction of vice and virtue is not founded merely on the relations of objects, nor is perceiv'd by reason."

Thirdly, Friedman contents himself with a mere empirical claim, un-backed by even a scintilla of evidence. $\mathrm{He}$ opines that public education benefits the entire society. How does he know that? He offers no proof. The alternative view is also plausible: much of what public education consists of is brainwashing students with the notion of United States' exceptionalism. This has enabled that country to become the policeman of the world and has invited terrorist retaliation. It has promoted feminist studies, black studies, queer studies, and other forms of political correctness, all to the harm of the general society. ${ }^{5}$

Rothbard's (1997, p. 178) reductio ad absurdum contended against this nonsense: "A and B often benefit, it is held, if they can force $\mathrm{C}$ into doing something. . . . [A]ny argument proclaiming the right and goodness of, say, three neighbors, who yearn to form a string quartet, forcing a fourth neighbor at bayonet point to learn and play the viola, is hardly deserving of sober comment." ${ }^{\text {" }}$

There are 18 states that regulate the content and delivery thereof in private and public schools (Hammons, 2008, p. 24-25). There it can be said that government has a monopoly on curriculum. In these states a voucher system would be pointless without heavy reform of education regulations. However the majority of the 32 states without such regulations do not require state accreditation of private schools. Alternative education institutions are free in these states to compete against the government. Competition becomes very onerous indeed when your rival, but not you, can rely on taxes and regulations.

\section{Public education}

Public education has the advantage of being an extension of the state, which has a monopoly on the legal use of force. It is a socialist institution that does not depend upon voluntary interactions to fund its operations. Attending a public school comes at no additional out of pocket cost to the student because the institution's funds have already been forcefully removed from the taxpayer and the student's attendance at a school is mandated, so there is no opportunity cost either. Private schools must not only outperform the state schools, but over and above that create the additional value of tuition for the consumer. To attend a private school a double tuition must be paid, once through taxes for the government schools and a second time for the private institution. ${ }^{7}$ For a minority of consumers the additional price of tuition is worth patronizing the higher quality free market alternatives. For the majority, the double tuition that must be paid to attend a private school exceeds the gains of a better education.

The average private high school, when adjusted for socioeconomic backgrounds, registers no difference in achievement test scores vis a vis its public counterpart (Cloud, 2007). Although private schools can obtain accreditation and create their own ways to signal student-achievement, a high school degree from a private school has the same value as one from a public school in the eyes of virtually all employers. Firms seek workers with high school diplomas, not because it means they have the job skills that are required, but because it indicates they have the necessary work ethic and perseverance.

The private school does have an advantage when it comes to entrance into college. They outperform public schools on SATs (Cloud, 2007), which, unlike achievement tests, focuses more on critical thinking skills. For the $31.7 \%$ (U.S. Bureau of Labor Statistics, 2012) of high school grads who do not go on to college, this advantage is of little or no economic concern. For the majority who do, it is difficult to see how over $\$ 110,000$ in private tuition over twelve years plus lifelong taxation for other 

overly misallocated into education. They must spend more time in school and pay more for college education than they otherwise would have. If we had a truly free enterprise economy, employers' educational expectations for their workers would tend to be congruent with actual productivity. Unfortunately, at present, we have a mixed economy, where the power of such market signals are greatly attenuated.

Government subsidizing education thus results in a boom and bust for the consumers of education and employers of recent graduates from higher academic institutions. ${ }^{8}$ Students go into college expecting to be able to achieve a greater income than they would have had it not been for the extra education. Their expectations are based on what graduates with the same degree have earned. This is determined by looking at beginning and-long term salaries of the expected job. However initial pay is based in part on the current supply of people with the degree and longer term compensation is dependent on the supply of people with degrees-earned in the past. As vouchers increase the number of students with a college degree employers begin to receive more applicants and must turn more people away. At this point students realize that their degrees are not worth as much as they thought they were. Their calculations are distorted because of government subsidies. The resulting unemployment and underemployment is the bust resulting from government funding. Students are then incentivized to go on to graduate schools and receive a more specialized degree that, besides distinguishing them from other job applicants, all too often produces no extra value for the student or the employer; for example, $\mathrm{PhDs}$ in feminist studies, black studies, queer studies, sociology, religion, literature and their ilk. This further artificially increases the structure of production for human capital. Can it be objected that vouchers do not subsidize educational establishments, per se, rather they finance pupils? No. Educational vouchers subsidize the entire industry, when compared to free enterprise, where neither schools nor students benefit from money mulcted from the long-suffering taxpayer. Vouchers may be an improvement in cost and outcome of education over public schools, but they still suffer from this market distortion (Forster, 2013).

Under our current system indebted students are creating an economic incentive for politicians to low- er the costs of college as a way to gain the youth vote. We see this now with President Barrack Obama trying to keep interest on student loans low (Feller, 2012; Kadlec, 2012), but these loans have existed as forms of politicians buying youth votes for decades. Under a voucher system this continues. Where there is government funding of private institutions, a framework is created that could easily be extended to also include the state payment of tuition at private colleges and universities.

M. Friedman and R. Friedman (1990, p. 152) distinguishe the problems of higher education from those of secondary and elementary. However, the problems with the former are affected by government policies of the latter. He arbitrarily chooses secondary education as the cutoff for a voucher system. Politicians or bureaucrats could easily increase voucher eligibility to include higher education. There is no compelling reason why high school should be the cutoff other than that it was historically the standard in the latter half of the last century. It was chosen because of historical coincidence, not any objective economic or educational consideration.

\section{Solutions}

Before looking for a solution for education, the goals of reform need to be determined. M. Friedman and R. Friedman (1990, p. 170) perceived the result of vouchers as being, "the quality of all schooling would rise so much that even the worst, while it might be relatively lower on scale, would be better in absolute quality." Quality may increase from vouchers but who is to say how high quality should be? Everyone in the economy could divert all of their labor and resources into education to maximize the quality, but there would be obvious insurmountable opportunity costs. The focus of education reform should not be to maximize the quality of education. The goal should be to maximize the value gained by individuals in all of their pursuits towards happiness, not just education. Friedman is effectively imposing his subjective value for education on everyone and ignoring the possibility that they may be able to use their time and capital to invest in more profitable opportunities.

Vouchers only exacerbate the problem with our current system. They reduce the return on education while its attempt to manufacture choice only misallo- 



\section{References}

Anderson, W. L., Block, W. E., DiLorenzo, T. J., Mercer, I., Snyman, L., \& Westley. C. (2001). The Microsoft Corporation in Collision with Antitrust Law. The Journal of Social, Political and Economic Studies, 26 (1), 287-302.

Armentano, D. T. (1999). Antitrust: The Case for Repeal (Revised $2^{\text {nd }}$ ed.). Auburn AL: Ludwig von Mises Institute.

Barnett, W. II, Block, W. E. (2007). Coase and Van Zandt on Lighthouses. Public Finance Review, 35 (6), 710-733.

Barnett, W. II, Block, W.E. (2009). Coase and Bertrand on Lighthouses. Public Choice, 140 (1-2), 1-13.

Barnett, W. II, Block, W. E. \& Saliba, M. (2005). Perfect Competition: A Case of 'Market-Failure', Corporate Ownership \& Control, 2 (4), 70-75.

Barnett, W. II, Block, W. E. \& Saliba, M. (2007). Predatory pricing. Corporate Ownership \& Control, 4 (3), 401-406.

Block, W. E. (1977). Austrian Monopoly Theory a Critique. The Journal of Libertarian Studies, 1 (4), 271-279.

Block, W. E. (1982). Amending the Combines Investigation Act, Vancouver, BC: The Fraser Institute.

Block, W. E. (1983). Public Goods and Externalities: The Case of Roads. The Journal of Libertarian Studies: An Interdisciplinary Review, 7 (1), 1-34.

Block, W. E. (1994). Total Repeal of Anti-trust Legislation: A Critique of Bork, Brozen and Posner. Review of Austrian Economics, 8 (1), 35-70.

Block, W. E. (1999). The gold standard: a critique of Friedman, Mundell, Hayek and Greenspan from the free enterprise perspective. Managerial Finance, 25 (5), 15-33.

Block, W. E. (2003A). Private property rights, economic freedom, and Professor Coase: A Critique of Friedman, McCloskey, Medema and Zorn. Harvard Journal of Law and Public Policy, 26 (3), 923-951.

Block, W. E. (2003B). National Defense and the Theory of Externalities, Public Goods and Clubs. In H. H. Hoppe (Ed.), The Myth of National Defense: Essays on the Theory and History of Security Production (pp. 301-334). Auburn, AL: Ludwig von Mises Institute.

Block, W. E. (2010A). Milton Friedman on Intolerance: A Critique. Libertarian Papers, 2 (41), 1-18. Retrieved from http://libertarianpapers.org/articles/2010/lp-2-41.pdf
Block, W. E. (2010B). Is Milton Friedman a libertarian? Laissez-Faire, 32, 9-22.

Block, W. E. (2011). How Not To Defend the Market: A critique of Easton, Miron, Bovard, Friedman and Boudreaux . Journal of Libertarian Studies, 22, 581-592.

Block, W. E., Barnett, W. II. (2009). Monopsony Theory. American Review of Political Economy, 7(1-2), 67-109.

Block, W. E., Barnett, W. II. (2012-2013). Milton Friedman and the financial crisis. American Review of Political Economy, 10 (1-2), 2-17.

Boudreaux, D. J., \& DiLorenzo, T. J. (1992). The Protectionist Roots of Antitrust. Review of Austrian Economics, 6 (2), 81-96.

U.S. Bureau of Labor Statistics. (2012). College Enrollment and Work Activity of 2011 High School Graduates.

Butts, R. F. (1973). The Public Schools: An Assault on a Great Idea. The Nation, 216 (18), 553-560.

Chappell, R. H. (1978). Anarchy Revisited: an inquiry into the public education dilemma. The Journal of Libertarian Studies, 2 (4), 357-372.

Cloud, J. (2007, October 10). Are Private Schools Really Better? Time. Retrieved from http://www.time. com/time/nation/article/0,8599,1670063,00.html

Cordato, R. E. (1992). Welfare Economics and Externalities in an Open-Ended Universe: A Modern Austrian Perspective. Boston, MA: Kluwer Academic Publishers.

Costea, D. (2003). A Critique of Mises's Theory of Monopoly Prices. The Quarterly Journal of Austrian Economics. 6 (3), 47-62.

Davis, W. L., Figgins, B., Hedengren, D., \& Klein, D. B. (2011). Economics Professors' Favorite Economic Thinkers, Journals, and Blogs (along with Party and Policy Views). Econ Journal Watch 8 (2), 126-146.

DiLorenzo, T. J. (1996). The Myth of Natural Monopoly. Review of Austrian Economics, 9 (2), 43-58.

DiLorenzo, T. J., High, J. C. (1988). Antitrust and Competition, Historically Considered. Economic Inquiry, 26 (1), 423-435.

Feller, B. (2012, April 24). Obama pushes low-rate student loans, wooing young. Retrieved from http:// news.yahoo.com/obama-pushes-low-rate-studentloans-wooing-young-202321208--finance.html 
Flew, A. (1976). Sociology, Equality and Education, London, UK: Macmillan.

Forster, G. (2013). A Win-Win Solution: The Empirical Evidence on School Choice ( $3^{\text {rd }}$ ed.). Indianapolis, IN: The Friedman Foundation for Educational Choice.

Frey C. M., Detterman, D. K. (2004). The Relationship Between the Scholastic Assessment Test and General Cognitive Ability. Psychological Science 15 (6), 373-378.

Friedman, M., Block, W. E. (2006). Fanatical, Not Reasonable: A Short Correspondence Between Walter E. Block and Milton Friedman (on Friedrich Hayek's Road to Serfdom). Journal of Libertarian Studies, 20 (3), 61-80.

Friedman, M. (1972). Capitalism and Freedom (12 ${ }^{\text {th }}$ ed.). Chicago, IL: University of Chicago Press.

Friedman, M. (1983, December 5). Milton Friedman on Busting the School Monopoly. Newsweek. Retrieved from http://www.edchoice.org/The-Friedmans/The-Friedmans-on-School-Choice/MiltonFriedman-on-Busting-the-School-Monopoly.aspx

Friedman, M., Friedman, R. (1990). Free to Choose: A Personal Statement. Orlando, FL: Harcourt Inc.

Garrison, R. W. (2001). Time and Money: The Macroeconomics of Capital Structure. London, UK: Routledge.

Gwartney, J., Lawson, R., \& Block, W. E. (1996). Economic Freedom of the World, 1975-1995. Vancouver, BC: The Fraser Institute.

Hammons, C. (2008). Fifty Educational Markets: A Playbook of State Laws and Regulations Governing Private Schools. School Choice Issues in Depth. Indianapolis, IN: Friedman Foundation for Educational Choice.

Hayek, F. A. (1931). Prices and Production, London, UK: Routledge.

Hayek, F. A. (1948). The Use of Knowledge in Society. Individualism and Economic Order, Chicago, IL: University of Chicago Press.

High, J. (1984-1985). Bork’s Paradox: Static vs Dynamic Efficiency in Antitrust Analysis. Contemporary Policy Issues, 3, 21-34.

Hoppe, H. H., (Ed.). (2003). National Defense and the Theory of Externalities, Public Goods and Clubs." The Myth of National Defense: Essays on the Theory and History of Security Production. Auburn, AL: Mises Institute.
Hume, D. (1739). A Treatise of Human Nature: Being an Attempt to Introduce the Experimental Method of Reasoning into Moral Subjects.

Illich, I. (1971). Deschooling Society. London, UK: Marion Boyars Publishers Ltd.

Jaworski, R. (2002, March 15). Friedman and Freedom. Milton Friedman interviewed by Peter Jaworski. The Journal (Queen's University, Canada), 37, 18-19.

Kadlec, C. (2012, May 14). Obama's Student Loan Gambit Devalues The Office Of The President. Forbes. Retrieved from http://www.forbes.com/sites/ charleskadlec/2012/05/14/obamas-student-loangambit-devalues-the-office-of-the-president/

Kinsella, S. (2009, November 9). Milton Friedman on Intolerance, Liberty, Mises, Etc. Retrieved from http://archive.mises.org/11004/milton-friedman-on-intolerance-liberty-mises-etc/

Lewin, P. (1982). Pollution Externalities: Social Cost and Strict Liability. Cato Journal, 2 (1), 205-229.

Liggio, L. P., Peden, J. R. (1978). Social Scientists, Schooling, and the Acculturation of Immigrants in 19th Century America. Journal of Libertarian Studies, 2 (1), 69-84.

Lott, J. (1987). Why is Education Publicly Provided? A Critical Survey. Cato Journal, 7 (2), 475-501.

Lott, J. (1990A). An Explanation for the Public Provision of Schooling: The Importance of Indoctrination. Journal of Law and Economics, 33 (1), 199-231.

Lott, J. (1990B). Why is Education Publicly Provided? Some Further Thoughts. Cato Journal, 10 (1), 293-241.

Lott, J. (1999). Public Schooling, Indoctrination, and Totalitarianism. Journal of Political Economy, 107 (S6), S127-S157.

Machan, T. R. (2010, June 7). Milton Friedman and the Human Good. Retrieved from http://mises.org/daily/4451/Milton-Friedman-and-the-Human-Good

McChesney, F. (1991). Antitrust and Regulation: Chicago's Contradictory Views. Cato Journal, 10 (3), 775-798.

Mises, L. von (1981). Socialism: An Economic and Sociological Analysis. Indianapolis, IN: Liberty Fund. (Original work published 1922).

Mises, L. von. (1998). Human Action: A Treatise of Economics. Scholars' Edition. Auburn, AL: Ludwig von Mises Institute. (Original work published 1949). 
Murray, C. (1984). Losing Ground: American Social Policy from 1950 to 1980, New York, NY: Basic Books.

National Center for Education Statistics. (n. d.). CCD Quick Facts. Retrieved from http://nces.ed.gov/ ccd/quickfacts.asp\#f3

National Center for Education Statistics. (n. d.). Digest of Education Statistics. Retrieved from http://nces. ed.gov/programs/digest/d10/tables/dt10_063.asp

Olasky, M. (1992). The Tragedy of American Compassion, Chicago, IL: Regnery Gateway.

Postiglione, G. (1982.) The Opponents of Public Education: New York State, 1870-1880. The Journal of Libertarian Studies, 6 (3-4), 359-376.

Richman, S. (1994). Separating School and State: How to Liberate America's Families. Fairfax, VA: The Future of Freedom Foundation.

Rickenbacker, W., Boaz, D. (Eds.). (1974). The Twelve Year Sentence: Radical Views of Compulsory Education. LaSalle, IL: Fox and Wilkes.

Rothbard, M. N. (2004). Man, Economy and State, Scholar's Edition. Auburn, AL: Ludwig von Mises Institute. (Original work published 1962).

Rothbard, M. N. (1972). Education, Free and Compulsory: The Individual's Education. Wichita, KS: Center for Independent Education.

Rothbard, M. N. (1973). For a New Liberty. The Libertarian Manifesto. New York, NY: Macmillan.

Rothbard, M. N. (1982). Law, Property Rights, and Air Pollution. Cato Journal, 2 (1), reprinted in Economics and the Environment: A Reconciliation, Walter Block, ed., Vancouver: The Fraser Institute, 1990. (Original work published in Cato Journal, 2 (1)).

Rothbard, M. N. (1993). Man, Economy, and State, Auburn, AL: Ludwig von Mises Institute.

Rothbard, M. N. (1997). The Logic of Action: Applications and Criticism from the Austrian School (Vol. 2). Cheltenham, UK: Edward Elgar.

Rothbard, M. N. (2002). Milton Friedman Unraveled. Journal of Libertarian Studies, 16 (4), 37-54.

Santoriello, A., Block, W.E. (1996). Externalities and the Environment. The Freeman, 46 (11), 755-756.

Shugart, W. F. II. (1987). Don't Revise the Clayton Act, Scrap It! Cato Journal, 6 (3), 925-932.

Smith, F. L. Jr. (1983, December 31). Why not Abolish Antitrust? Regulation, 23-33.
Sowell, T. (1993). Inside American Education: The Decline, the Deception, The Dogmas. New York, NY: The Free Press.

Spring, J. H. (1972). Education and the Rise of the Corporate State. Boston, MA: Beacon Press.

Terrell, T. D. (1999). Property Rights and Externality: The Ethics of the Austrian School. Journal of Markets and Morality, 2 (2), 197-207.

Tucker, J. (1998A). Controversy: Are Antitrust Laws Immoral? Journal of Markets \& Morality, 1 (1), 75-82.

Tucker, J. (1998B). Controversy: Are Antitrust Laws Immoral? A Response to Kenneth G. Elzinga. Journal of Markets \& Morality, 1 (1), 90-94.

Vance, L. M. (2005, April 21). The Curse of the Withholding Tax. Retrieved from http://mises.org/daily/1797

West, E. G. (1964). Private versus Public Education: A Classical Economic Dispute. Journal of Political Economy, 72 (5), 465-475.

West, E. G. (1965). Education and the State: A Study in Political Economy. London, UK: The Institute of Economic Affairs.

West, E. G. (1967). The Political Economy of Public School Legislation. Journal of Law and Economics, 10, 101-128.

Wilcke, R. R. (1999). An appropriate ethical model for business, and a critique of Milton Friedman. Paper presented at Proceedings of Ludwig von Mises Institute "Austrian Scholars Conference", April 1617, 1999, Auburn: AL.

Williams, W. E. (1982). The State Against Blacks, New York, NY: McGraw-Hill.

Woods, T. E. Jr. (2009). Meltdown: A Free-Market Look at Why the Stock Market Collapsed, the Economy Tanked, and Government Bailouts Will Make Things Worse. Washington, DC: Regnery Publishing.

\section{Endnotes}

1 This is certainly compatible with the free enterprise supposedly supported by Friedman

2 This is certainly not compatible with the free enterprise supposedly supported by Friedman

3 For evidence in support of this contention, see Block, 1999, 2003A, 2010A, 2010B, 2011; Block and Barnett, 2012-2013; Friedman and Block, 
2006; Friedman and Block, 2006; Kinsella, 2009; Machan, 2010; McChesney, 1991; Rothbard, 2002; Vance, 2005; Wilcke, 1999.

4 See on this Anderson, et. al., 2001; Armentano, 1999; Barnett, et. al., 2005, 2007; Block, 1977, 1982, 1994; Block and Barnett, 2009; Boudreaux and DiLorenzo, 1992; Costea, 2003; DiLorenzo, 1997; DiLorenzo and High, 1988; High, 1984-1985; McChesney, 1991; Rothbard, 2004; Shugart, 1987; Smith, 1983; Tucker, 1998A, 1998B.

5 The present authors do not maintain that these claims are true, either, in the absence of supplying evidence for them, which would take us far too far afield. We mention them herein, only, to highlight our view that Friedman's claim, too, is offered on the basis of no evidence whatever.

6 For a further critique of this pernicious doctrine of Friedman's (1972) see Barnett and Block, 2007, 2009; Block, 1983, 2003B; Cordato, 1992; Hoppe, 2003; Lewin, 1982; Rothbard, 1982; Santoriello and Block, 1996. Terrell, 1999.

7 Literature supporting this claim may be found here: Butts, 1973; Chappell, 1978; Flew, 1976; Friedman, 1972; Illich, 1970; Liggio and Peden, 1978; Lott, 1987; 1990A; 1990B; 1999; Postiglione, 1982; Richman, 1994; Rickenbacker, 1974; Rothbard, 1972; Sowell, 1993; Spring, 1972; West 1964; 1965; 1967.

8 There is an analogy, but not a congruence, with Austrian Business Cycle Theory, which relies on credit expansion and artificially lowered interest rates. See Garrison, 2001; Hayek, 1931; Mises, 1998; Rothbard, 1993; Woods, 2009.

9 This is done with funds taken by force from the donors; in any other context, this would be recognized for the theft it really is 
